\title{
Tympanoplasty type 1 in the treatment of patients with sclerotic mastoid: anatomical and functional results
}

\section{Sklerotik mastoid kemiğe sahip kronik otitis medialı hastalarda tip 1 timpanoplasti: Anatomik ve fonksiyonel sonuçlar}

\author{
Rıza Dündar', Fatih Kemal Soy², Erkan Kulduk², Can Özbay³, Yılmaz Özkul' , Ahmet Yükkaldıran' \\ ${ }^{1}$ Department of Otorbinolaryngology, Harran University Medical Faculty, Şanluurfa, Turkey \\ ${ }^{2}$ Department of Otorhinolaryngology, Mardin Government Hospital, Mardin, Turkey \\ ${ }^{3}$ Department of Otorbinolaryngology, Adnan Menderes University Medical Faculty, Aydin, Turkey \\ ${ }^{4}$ Department of Otorbinolaryngology, Izmir Katip Çelebi University Medical Faculty, Izmir, Turkey
}

\begin{abstract}
Objective: To evaluate success of tympanoplasty type 1 in the treatment of patients with sclerotic mastoid bone.

Methods: A retrospective study where 92 patients with noncholesteatomatous chronic suppurative otitis media were recruited during the period of 2010 to 2012. Patients were managed medically and after dryness of their perforations they were operated upon. Ninety-two patients underwent type 1 tympanoplasty alone without cortical mastoidectomy. Underlay technique with chondroperichondrial graft was performed for all patients.

Results: Mean air-bone gap values were estimated and compared. In pre- and postoperative audiograms, air-bone gap values at 500, 1000, 2000 and $4000 \mathrm{~Hz}$ frequencies were determined. Pre- and postoperative mean air-bone gap values of the patients were $23.47 \pm 4.95$ and $11.58 \pm 4.77 \mathrm{~dB}$, respectively.

Conclusion: Our study emphasizes the fact that overall satisfactory hearing outcome with adequate air-bone closure can be achieved irrespective of cortical mastoidectomy in the surgical treatment of noncomplicated chronic ear diseases.
\end{abstract}

Keywords: Tympanoplasty, mastoidectomy, chronic otitis media.

\section{Özet}

Amaç: Sklerotik mastoid kemiğe sahip hastaların tedavisinde mastoidektomisiz tip 1 timpanoplastinin başarısını değerlendirmeyi amaçladik.

Yöntem: Retrospektif olarak yapılan bu çalışmaya 2010-2012 yılları arasında kronik otitis media tanısı konarak mastoidektomisiz tip 1 timpanoplasti yapılan 92 hasta alındı. Medikal tedavi sonrası kulak akıntıları kesilen hastalara underlay teknikle kondroperikondrial greft ile timpan membran rekonstrüksiyonu yapıldı.

Bulgular: Ortalama hava kemik yolu değerleri operasyon öncesi ve sonrası değerlendirildi. 500, 1000, 2000, ve $4000 \mathrm{~Hz}$ frekanslarında yapılan odiyogramlarla hava kemik yolu aralığı hesaplandı. Preoperatif dönemde ortalama hava kemik yolu değeri $23.47 \pm 4.95 \mathrm{~dB}$ iken bu değer postoperatif dönemde $11.58 \pm 4.77 \mathrm{~dB}$ olarak hesapland.

Sonuç: Çalışmamızda sklerotik mastoid kemiğe sahip hastalarda yapılacak olan tip 1 timpanoplasti operasyonunda işitme kazancı ve greft başarısı tatmin edici düzeyde bulunmuştur.

Anahtar sözcükler: Tip 1 timpanoplasti, mastoidektomi, kronik otitis media.

encountered in the human race and is as old as humanity itself. $^{[1]}$ The primary goals in the treatment of chronic ear disease are to eradicate the disease, prevent recurrence,
Chronic otitis media (COM) is an inflammatory process of the mucoperiosteal lining of the middle ear space and mastoid. Infection of the middle ear has been a problem
Online available at:

Correspondence: Riza Dündar, Assist. Prof. Department of Otorhinolaryngology, Harran University Medical Faculty, Şanlıurfa, Turkey.

e-mail: dundarkbb2@gmail.com

Received: November 20, 2014; Accepted: December 7, 2014 www.jmedupdates.org doi: $10.2399 /$ jmu.2014003003 QR code: 
restore optimal hearing and maintain a dry ear. The two major treatment options used to accomplish these goals are canal wall-up $(\mathrm{CWU})$ and canal wall-down (CWD) mastoidectomies. In general, the CWU procedure is designed to maintain the normal anatomic contours of the mastoid cavity and preserve the anatomy of the posterior canal wall. ${ }^{[2]}$

Even though, mastoidectomy performed concomitantly with tympanoplasty procedures in COM patients with perforated tympanic membrane is still frequently used, in recent years it has become a debatable issue. Studies advocating the necessity of mastoidectomy have either recommended mastoidectomy in all dry and suppurative $\mathrm{COM}^{[3,4]}$ or opinions are in favour of performing mastoidectomy only for suppurative $\mathrm{COM}^{\left[{ }^{[5-7]}\right.}$ Besides, some authors are against mastoidectomy in both dry and suppurative COM without cholesteatoma. ${ }^{[8,9]}$

In this study, we have retrospectively investigated the patients diagnosed as chronic otitis media without cholesteatomas, but with radiologically detected sclerotic mastoid who had undergone tympanoplasty without mastoidectomy. We have tried to compare pre- and postoperative anatomic and functional outcomes.

\section{Materials and Methods}

In the present study, 92 cases who had had type 1 tympanoplasty without mastoidectomy between 2010 and 2012 were retrospectively analyzed. Patients older than 14 years of age with tympanic membrane perforation, sclerotic mastoid cells as detected on temporal bone CT, without any ossicular abnormalities and aural discharge for at least 3 months were included in the study.

Inclusion criteria for the study were: (1) age $>14$-years, (2) dry perforation and at least for three month "dry and quiescent ears", (3) central or subtotal perforation, (4) presence of a sclerotic mastoid bone. Exclusion criteria for the study were: (1) age <14-years, (2) wet ear, (3) marginal or attic perforation, (4) cholesteatomatous ear, (5) associated systemic disease, (6) previous mastoid operation.

Detailed medical history was obtained from all patients including onset, course and duration of the disease, associated symptoms, previous medications and operations or trauma. Patients were subjected to full otological examinations so as to exclude scar of the previous operation and evaluate tympanic membrane and middle ear mucosa. Besides, tuning fork tests, nasal and oral examinations were performed to exclude predisposing factors as allergy or causes of recurrences. All patients were subjected to preoperative pure tone audiometry tests which were repeated at postoperative 3rd month. Routine preoperative lab tests were done for all patients. Patients were evaluated at postoperative 12th month with audiograms to determine the actual state of the tympanic membrane graft and level of hearing. All cases were operated by a single surgeon (R.D.) under general anesthesia.

As a standard procedure, via endaural approach, tympanomeatal flap was elevated to expose ossicular system and aditus up to mastoid antrum. Since any pathological tissue was not detected in this region, boomerang shaped chondoperichondrial graft was used for underlay grafting.

Amoxicillin clavulanic acid tablets $(1 \mathrm{~g}$ x 2 /day) were prescribed for all patients. The first postoperative visit was on the 10th day, during which the ear dressing, packing and skin sutures were removed. After removal of the dressing, the patient was instructed to keep their ears dry. Rifampicin SV solution was applied by the patients to the postauricular incision site twice a day for 1 week. The second follow-up visit was planned for 3-4 weeks later. Thereafter, the patients were monitored at postoperative 3rd month until the graft take could be evaluated using comparative postoperative audiograms.

All patients were compared as for pre- and postoperative state of graft take, graft retraction and air bone gap values. Data were evaluated using Microsoft Office Excel 2010 (Microsoft Comp. Chicago, IL, USA) and Statistical Package for Social Sciences 16.0 for Windows (SPSS Inc., Chicago, IL, USA). p $<0.05$ was accepted as a statistically significance level.

\section{Results}

All of the operated 92 patients (male, $\mathrm{n}=34$ and female, $\mathrm{n}=58$ ) were retrospectively analyzed. The patients aged between 16-48 years with a mean age of $27.6 \pm 5.65$ years. The patients were followed up for 21.5 months.

At postoperative 3rd, 6th, 9th and 12 th months, medical files of the patients were reviewed and reperforations were detected in $9(9.8 \%)$ of 92 patients and closure of the perforations was noted in $83(90.2 \%)$ patients.

Hearing test results: Mean air-bone gap (ABG) values were estimated and compared. In pre- and postoperative audiograms, air-bone gap values at 500, 1000, 2000 and $4000 \mathrm{~Hz}$ frequencies were determined. During preoperative period mean $\mathrm{ABG}$ value of the patients was $23.47 \pm 4.95 \mathrm{~dB}$. 
During postoperative period, mean $\mathrm{ABG}$ value of the patients was $11.58 \pm 4.77 \mathrm{~dB}$ (Fig. 1). Pre- and postoperative evaluations of patients revealed that tympanoplasty without mastoidectomy procedures provided significant improvements in hearing functions. Pre- and postoperative audiogram results of patients were statistically significant $(p<0.0001)$. However postoperative $A B G$ values were significantly better than preoperative values in all patients (preoperative $A B G \mathrm{p}=0.023$, postoperative $\mathrm{ABG}$ $\mathrm{p}=0.037)$.

Graft retraction was observed in five of 92 patients $(5.4 \%)$ at postoperative 1 st year. The graft retractions were localized at central zone in 2 and at posterosuperior zone in 3 patients, while only $2(3.8 \%)$ graft retractions were observed at central zone in Group B. All retractions were grade 1 according to Sade classification.

\section{Discussion}

Mastoidectomy was first described by Louis Petit in the 1700s, although the concept did not gain wider acceptance until 1958, when the cortical mastoidectomy was popularized by William House. This procedure attempted to avoid the common problems seen with radical mastoidectomy. ${ }^{[10]}$

Type 1 tympanoplasty is an operative procedure, in which the reconstructive procedure is limited to the repair of the tympanic membrane perforation. There are a number of studies in the literature highlighting the advantages and disadvantages of performing mastoidectomy in the surgical treatment of mucosal type chronic otitis media.

Our study emphasizes the fact that overall satisfactory hearing outcome with adequate air-bone closure can be achieved irrespective of cortical mastoidectomy. Pre- and postoperative A-B gaps were detected as $23.47 \pm 4.951 \mathrm{~dB}$ and $11.58 \pm 4.765 \mathrm{~dB}$, respectively.

In the surgical treatment of COM especially in noncholesteatomatous cases mastoidectomy is not always a necessary intervention. ${ }^{[9]}$ Sheehy recommended simple cortical mastoidectomy in all tympanoplasty operations as a routine procedure. ${ }^{[3]}$ Tos also recommended mastoidectomy for draining ears, but also indicated that they could not always achieve improved outcomes. ${ }^{[6]}$ Despite these expert opinions, many other authors have thought that mastoidectomy should be added to tympanoplasty to increase the chance of graft success in cases with chronic cases with suppurative ears who were undergoing revision surgery. ${ }^{[1]}$ The most important justification for mas-

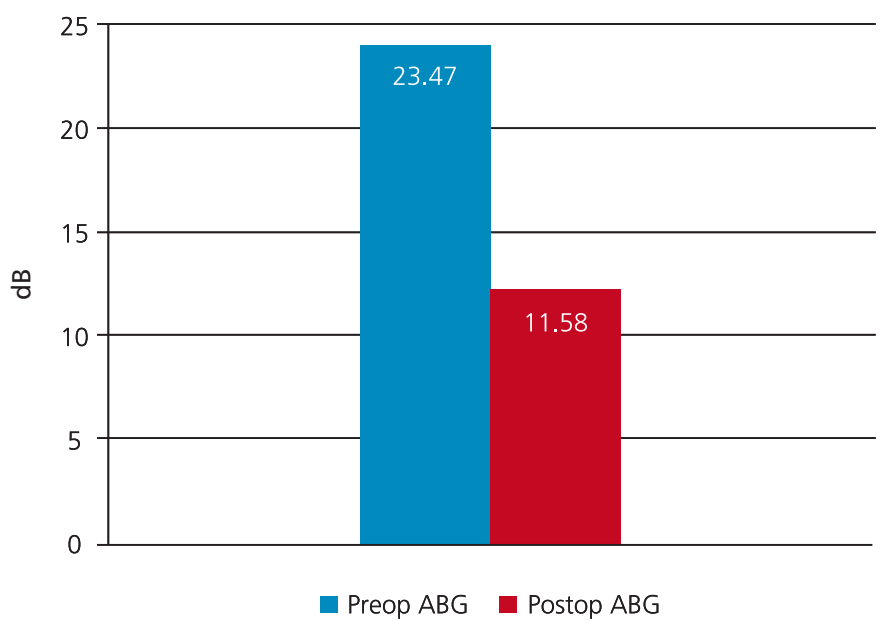

Fig. 1. Air-bone gap in $\mathrm{dB}$ pre- and postoperatively.

toidectomy is that this operation would provide better drainage of the middle ear effusion and opening mastoid air cells would increase aeration which all would facilitate regression of the disease. ${ }^{[12]}$ Toros et al. evaluated tympanoplasty with or without mastoidectomy performed in patients with sclerotic mastoid bone, as for hearing results and graft success and could not find any statistically significant difference between both groups. They indicated that simple mastoidectomy is an effective intervention in establishing repneumatization of the sclerotic mastoid cells and eradication of infection within mastoid bones. However, they also asserted that especially in cases scheduled for only myringoplasty, its added benefits, potential risks and cost-effectiveness should be meticulously evaluated. ${ }^{[13]}$

In our clinics, we routinely obtain temporal bone CTs for all patients with detected COM for the last 20 months. We perform tympanomastoidectomy through an postauricular approach in cases with available computed tomographic evidence favouring cholesteatoma in the middle ear or mastoid bone. However, in cases with sclerosing and/or pneumatized mastoid bone, we perform tympanoplasty via endaural route. In these cases, posterosuperior wall is curetted to expose aditus up to mastoid antrum and ossicular system. In the presence of abnormal tissue (granulation, epithelium and polyp) in the aditus, anterior atticoantrostomy is performed to get rid of these tissues. 
Mc Grew et al. could not find any statistically significant difference between patients who had undergone tympanoplasty with or without mastoidectomy as for success rates of grafting and auditory outcomes. ${ }^{[4]}$ Balyan et al. reported that in cases with non-cholesteatomatous COM, mastoidectomy as an adjunct to tympanoplasty has no effect on success rates of closure of tympanic perforation and functional hearing outcomes, not mentioning extra burden and risk it incurs. ${ }^{[14]}$ Mishiro et al. disclosed midterm and long-term follow-up results of the patients who had undergone tympanoplasty with or without mastoidectomy and could not find any difference between hearing outcomes and graft success rates. Besides, they indicated that in cases with non-cholesteatomatous chronic otitis media and tympanic membrane perforation, mastoidectomy could not be performed and in infected ears caution should be instituted. They also reported that tympanoplasty without mastoidectomy could be performed under local anesthesia which might be preferred especially in the elderly and patients with medical complications. ${ }^{[15]}$ In this study also the risks caused by mastoidectomy were reported. As far as we know, sensorineural hearing loss may occur because of drill trauma, secondary meningitis may develop because of dura mater trauma at tegmen tympani zone, massive bleeding may be served due to sigmoid sinus trauma and facial nerve injury may occur during mastoidectomy.

In our study, we evaluated patients with sclerotic mastoid bone who had undergone tympanoplasty type 1 without mastoidectomy. We have not detected any statistically significant difference between pre- and postoperative hearing outcomes. Closure of tympanic membrane perforation was performed at the end the first year and reperforations were in $9.8 \%(n=9)$ of the patients who had not undergone mastoidectomy.

Mane et al. reported graft take rate as $96 \%$, with no retraction pockets or displaced grafts observed during follow-up in their series of 14 patients. ${ }^{[16]}$ In our study we observed five cases of retractions (5.4\%) within the 1 st postoperative year. The retractions were at central zone in 2 and at posterosuperior zone in 3 of 92 patients. All retractions were grade 1 according to Sade classification. ${ }^{[17]}$

As limitations of our study, all the patients included in the study had dry ears and we could not evaluate the eustachian function of the patients. Longer follow-up period would have added value to the present study.
In conclusion, in cases without cholesteatoma who are scheduled for tympanoplasty, mastoidectomy does not create statistically significant differences regarding graft success and postoperative hearing outcomes, on the contrary it prolongs operative times in addition to its risks and financial burden.

\section{Conclusion}

Our study emphasizes the fact that overall satisfactory hearing outcome with adequate air-bone closure can be achieved irrespective of cortical mastoidectomy in the surgical treatment of chronic ear disease. When considering the addition of a mastoidectomy to a type 1 tympanoplasty, the performing surgeon should consider not only the potential added benefit but also potential risks and costs to the patient.

\section{Conflict of Interest: No conflicts declared.}

\section{References}

1. Smyth GD. Tympanic reconstruction. Fifteen year report on tympanoplasty. Part II. J Laryngol Otol 1976;90:713-41.

2. Dodson EE, Hashisaki GT, Hobgood TC, Lambert PR. Intact canal wall mastoidectomy with tympanoplasty for cholesteatoma in children. Laryngoscope 1998;108:977-83.

3. Sheehy JL. Mastoidectomy: the intact canal wall procedure. In: Brackmann DE, editor. Otologic surgery. Philadelphia: WB Saunders; 1994. p. 211-24

4. McGrew BM, Jackson G, Glascock ME III. Impact of mastoidectomy on simple tympanic membrane perforation repair. Laryngoscope 2004;114:506-11.

5. Lau T, Tos M. Long-term results of surgery for chronic granulation otitis media. Am J Otolaryngol 1986;7:341-5.

6. Tos M. Indications for surgery and preoperative management. In: Tos M, editor. Manual of middle ear surgery. New York: Thieme; 1993. p. 5.

7. Vartiainen E, Kansanen M. Tympanomastoidectomy for chronic otitis media without cholesteatoma. Otolaryngol Head Neck Surg 1992;106:230-4.

8. Mutoh T, Adachi O, Tsuji K, et al. Efficacy of mastoidectomy on MRSA-infected chronic otitis media with tympanic membrane perforation. Auris Nasus Larynx 2007;34:9-13.

9. Webb B, Chang YJ. Efficacy of tympanoplasty without mastoidectomy for chronic suppurative otitis media. Arch Otolaryngol Head Neck Surg 2008;134:1155-8.

10. Martin MS, Yaz R. Mastoid surgery. In Myers EN, editor. Operative otolaryngology: head and neck surgery, 2nd ed. Philadelphia: Saunders Elsevier; 2008. p. 1163-76.

11. Ruhl CM, Pensak ML. Role of aerating mastoidectomy in non cholesteatomatous chronic otitis media. Laryngoscope 1999;109:1924-7. 
12. Holmquist J, Bergström B. The mastoid air cell system in ear surgery. Arch Otolaryngol 1978;104:127-9.

13. Toros SZ, Habesoglu TE, Habesoglu M, et al. Do patients with sclerotic mastoids require aeration to improve success of tympanoplasty? Acta Otolaryngol 2010;130:909-12.

14. Balyan F, Celikkanet S, Aslan A, et al. Mastoidectomy in noncholesteatomatous chronic suppurative otitis media: is it necessary? Otolaryngol Head Neck Surg 1997;117:592-5.
15. Mishiro Y, Sakagami M, Kondoh K, Kitahara T, Kakutani C. Long-term outcomes after tympanoplasty with and without mastoidectomy for perforated chronic otitis media. Eur Arch Otorhinolaryngol 2009;266:819-22.

16. Mane R, Patil B, Mohite A, Varute VV. Bilateral type 1 tympanoplasty in chronic otitis media. Indian J Otolaryngol Head Neck Surg 2013;65:293-7.

17. Sade J. The atelectatic ear. In: Sade J, editor. Secretory otitis media and its sequelae. London: Churchill Livingstone; 1979. p. 64-8.

This is an open access article distributed under the terms of the Creative Commons Attribution-NonCommercial-NoDerivs 3.0 Unported (CC BYNC-ND3.0) Licence (http://creativecommons.org/licenses/by-nc-nd/3.0/) which permits unrestricted noncommercial use, distribution, and reproduction in any medium, provided the original work is properly cited.

Please cite this article as: Dündar R, Soy FK, Kulduk E, Özbay C, Özkul Y, Yükkaldıran A. Tympanoplasty type 1 in the treatment of patients with sclerotic mastoid: anatomical and functional results. J Med Updates 2014;4(3):94-98. 